\title{
The voltage-dependent $\mathrm{K}^{+}$channels Kv1.3 and Kv1.5 in human cancer
}

\author{
Núria Comes ${ }^{1}$, Joanna Bielanska ${ }^{1}$, Albert Vallejo-Gracia ${ }^{1}$, Antonio Serrano-Albarrás ${ }^{1}$, \\ Laura Marruecos ${ }^{2}$, Diana Gómez ${ }^{2}$, Concepció Soler ${ }^{2}$, Enric Condom ${ }^{2}$, Santiago Ramón y Cajal ${ }^{3}$, \\ Javier Hernández-Losa ${ }^{3}$, Joan C. Ferreres ${ }^{3}$ and Antonio Felipe ${ }^{1 *}$
}

${ }^{1}$ Molecular Physiology Laboratory, Departament de Bioquímica i Biologia Molecular, Institut de Biomedicina, Universitat de Barcelona, Barcelona, Spain

${ }^{2}$ Departament de Patologia i Terapèutica Experimental, Hospital Universitari de Bellvitge-IDIBELL, L'Hospitalet de Llobregat, Barcelona, Spain

${ }^{3}$ Departament de Anatomía Patològica, Hospital Universitari Vall d'Hebron, Universitat Autònoma de Barcelona, Barcelona, Spain

Edited by:

Andrea Becchetti, University of Milano-Bicocca, Italy

Reviewed by:

Irena Levitan, University of Illinois at

Chicago, USA

Dandan Sun, University of

Pittsburgh, USA

\section{${ }^{*}$ Correspondence:}

Antonio Felipe, Molecular

Physiology Laboratory, Departament de Bioquímica i Biologia Molecular.

Institut de Biomedicina, Universitat

de Barcelona, Avda Diagonal 643,

E-08028 Barcelona, Spain

e-mail: afelipe@ub.edu
Voltage-dependent $\mathrm{K}^{+}$channels $(\mathrm{Kv})$ are involved in a number of physiological processes, including immunomodulation, cell volume regulation, apoptosis as well as differentiation. Some Kv channels participate in the proliferation and migration of normal and tumor cells, contributing to metastasis. Altered expression of Kv1.3 and Kv1.5 channels has been found in several types of tumors and cancer cells. In general, while the expression of Kv1.3 apparently exhibits no clear pattern, Kv1.5 is induced in many of the analyzed metastatic tissues. Interestingly, evidence indicates that Kv1.5 channel shows inversed correlation with malignancy in some gliomas and non-Hodgkin's lymphomas. However, Kv1.3 and Kv1.5 are similarly remodeled in some cancers. For instance, expression of Kv1.3 and Kv1.5 correlates with a certain grade of tumorigenicity in muscle sarcomas. Differential remodeling of Kv1.3 and Kv1.5 expression in human cancers may indicate their role in tumor growth and their importance as potential tumor markers. However, despite of this increasing body of information, which considers Kv1.3 and Kv1.5 as emerging tumoral markers, further research must be performed to reach any conclusion. In this review, we summarize what it has been lately documented about Kv1.3 and Kv1.5 channels in human cancer.

Keywords: $\mathrm{K}^{+}$channels, cancer, agressiveness, tumor markers, proliferation

\section{VOLTAGE-DEPENDENT $\mathrm{K}^{+}$CHANNELS Kv1.3 AND Kv1.5}

Potassium channels are one of the most diverse and ubiquitous families of membrane proteins and are encoded by more than 75 different genes (Caterall et al., 2002). Voltage-dependent $\mathrm{K}^{+}$ channels (Kv), a superfamily comprised of 12 subfamilies (Kv1$\mathrm{Kv12}$ ), play a key role in the maintenance of resting membrane potential and the control of action potentials (Hille, 2001). Kv channels also contribute to a wide variety of cellular processes including the maintenance of vascular smooth muscle tone (Yuan et al., 1998), cell growth (DeCoursey et al., 1984), the regulation of cell volume (Deutsch and Lee, 1988), adhesion (Itoh et al., 1995), mobility, epithelial transport (Kupper et al., 1995), homeostasis (Xu et al., 2003), insulin release (Xu et al., 2004), and apoptosis (Storey et al., 2003). Kv channels also control leukocyte membrane potential and play a role in immune system responses (Cahalan and Chandy, 2009). Accordingly, several studies have reported that $\mathrm{Kv}$ channels are involved in the activation, proliferation, differentiation, and migration of leukocytes (Cahalan and Chandy, 1997; Wulff et al., 2003; Panyi et al., 2004; Beeton et al., 2005; Felipe et al., 2006). Given their pivotal role in cell physiology, abnormalities in $\mathrm{Kv}$ functions can lead to several channelopathies (Ashcroft, 2000).

The voltage dependent $\mathrm{K}^{+}$channels Kv1.3 and Kv1.5 are members of the Shaker (Kv1) family of $\mathrm{K}^{+}$channels and are implicated in tissue differentiation and cell growth (Felipe et al., 2006). Although Kv1.3 was first cloned from brain tissue, its expression is widely distributed throughout the body (Swanson et al., 1990; Bielanska et al., 2009, 2010). This channel is highly expressed in lymphocytes and the olfactory bulb (Stuhmer et al., 1989), and several studies have reported that it is also expressed in the hippocampus (Veh et al., 1995), epithelia (Grunnet et al., 2003), adipose tissue (Xu et al., 2004), and both skeletal, and smooth muscle (Villalonga et al., 2008; Bielanska et al., 2012a,b).

Kv1.3 currents exhibit a characteristic cumulative inactivation and a marked C-type inactivation. The single channel conductance of $\mathrm{Kv} 1.3$ is $13 \mathrm{pS}$, and the voltage required for activation is $-35 \mathrm{mV}$. In contrast, the Kv1.5 channel was first isolated from the human ventricle and is also expressed in the atria (Tamkun et al., 1991). Similar to the Kv1.3 channel, Kv1.5 is also ubiquitously expressed (Swanson et al., 1990; Bielanska et al., 2009, 2010). For example, Kv1.5 is expressed in the immune system, the kidney, skeletal and smooth muscle and, to a lesser extent, the brain (Coma et al., 2003; Vicente et al., 2003, 2006; Villalonga et al., 2008; Bielanska et al., 2012a,b). Kv1.5 currents contribute to the ultra-rapid activating $\mathrm{K}^{+}$current in the heart known as $\mathrm{I}_{\text {kur }}$, which plays a role in the repolarization of an action potential (Lesage et al., 1992). The conductance of the Kv1.5 channel is $8 \mathrm{pS}$, and the voltage required for activation is $\sim 24 \mathrm{mV}$. Unlike $\mathrm{Kv} 1.3, \mathrm{Kv} 1.5$ inactivation is slow and lacks cumulative inactivation. Such a different biophysical features may explain their distinct regulation in a number of cell types. 
Kv1.3 and Kv1.5 are inhibited by 4-aminopyridine (4-AP) and tetraethylammonium (TEA), which are general $\mathrm{K}^{+}$channel blockers (Grissmer et al., 1994). Psora-4 is another potent chemical inhibitor of both Kv1.3 and Kv1.5 and has a comparatively lesser effect on the rest of the $\mathrm{Kv}$ isoforms (Vennekamp et al., 2004). Highly specific toxins such as charybdotoxin and margatoxin (Leonard et al., 1992; Garcia-Calvo et al., 1993) as well as the anemone peptide ShK and their derivatives (Cahalan and Chandy, 1997) have proven to be highly effective for Kv1.3. On the other hand, Kv1.5 is highly insensitive to Kv1.3 blockers and has no known specific pharmacology. However, new chemicals such as S0100176 (from Sanofi-Aventis) (Decher et al., 2004) or diphenyl phosphine oxide-1 (DPO-1) have been discovered to potently inhibit Kv1.5 (Du et al., 2010).

Leukocytes express a diverse and unique repertoire of Kv proteins, however, Kv1.3 and Kv1.5 are considered the major Kv channels (Cahalan et al., 2001; Vicente et al., 2003, 2006; Wulff et al., 2004; Beeton et al., 2005; Cahalan and Chandy, 2009; Rangaraju et al., 2009; Sole et al., 2009; Felipe et al., 2010). In macrophages, dendritic cells and B lymphocytes, Kv currents are mainly mediated by Kv1.3, however, in contrast to T-lymphocytes, they also express Kv1.5 (Douglass et al., 1990; Vicente et al., 2003, 2006; Wulff et al., 2004; Mullen et al., 2006; Villalonga et al., 2007a,b; Zsiros et al., 2009; Villalonga et al., 2010a,b). We have previously shown that Kv1.5 subunits can coassemble with Kv1.3 subunits to generate functional heterotetrameric channels in macrophages. Interestingly, changes in the stoichiometry of the heterotetramers lead to the formation of new channels, which display different biophysical and pharmacological properties and influence the activation of specific cellular responses (Vicente et al., 2003, 2006, 2008; Villalonga et al., 2007a,b). The voltage for activation of Kv1.3 channel is more hyperpolarized than for Kv1.5. Thus, at physiological membrane potentials of most mammalian cells (from -30 to $-60 \mathrm{mV}$ ), Kv1.3/Kv1.5 heteromeric channels with a high Kv1.3 ratio would be much more activated than those with low ratios of Kv1.3. The distinct voltage activation threshold of the two channels would explain why different subunit composition in Kv1.3/Kv1.5 complexes can lead to specific alteration of cellular excitability and determine different cell responses. Thus, the expression level of both subunits can influence the degree of cell proliferation, differentiation or activation. In this context, the Kv1.3/Kv1.5 ratio may be an accurate indicator of cell activation. For example, high levels of Kv1.5 would suggest a cell was maintaining an immunosuppressive state, whereas increased

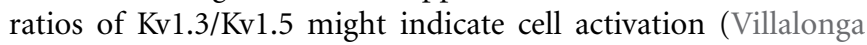
et al., 2007a,b; Felipe et al., 2010; Villalonga et al., 2010a,b). Leukocytes also express several regulatory subunits (Vicente et al., 2005; Sole et al., 2009) which may associate with Kv1.3/Kv1.5 complexes to enhance diversity and modulate a wide variety of physiological activities (McCormack et al., 1999). In fact, both channels Kv1.3 and Kv1.5, are able to assemble with $\mathrm{Kv} \beta$ subunits to form functional $\mathrm{Kv}$ channels. $\mathrm{Kv} \beta$ subunits alter current amplitude and gating, confer rapid inactivation, and promote Kv surface expression (Nakahira et al., 1996; Sewing et al., 1996; McCormack et al., 1999). In addition, heterologous expression of Kv1.3 and Kv1.5 with $\mathrm{Kv} \beta$ subunits in Xenopus oocytes and mammalian cells, dramatically modifies the rate of inactivation
(Sewing et al., 1996) and the $\mathrm{K}^{+}$current density (McCormack et al., 1999), respectively.

Although most studies have been performed in adult tissues, Kv channels are differentially expressed throughout development. To date, several important differences in $\mathrm{Kv}$ expression during neonatal development have been reported (Roberds and Tamkun, 1991; Lesage et al., 1992; Felipe et al., 1994; Coma et al., 2002; Grande et al., 2003; Tsevi et al., 2005). We have recently studied the expression pattern of Kv1.3 and Kv1.5 in detail during the early stages of human development, and we have noted the following observations: (1) numerous tissues express Kv1.3 and Kv1.5 channels, (2) both channels are abundantly expressed in fetal liver (Bielanska et al., 2010), which serves as a hematopoietic tissue during early gestation, (3) adult hepatocytes did not express Kv1.3 (Vicente et al., 2003), (4) Kv1.5 is strongly expressed in fetal muscle and heart, whereas Kv1.3 abundance is low, (5) human fetal skeletal muscle expresses slightly more Kv1.3 than adult muscle fibers (Bielanska et al., 2010), and (6) the Kv1.5 channel is predominantly located in adult skeletal muscle and exhibits a cell cycle-dependent regulation pattern (Villalonga et al., 2008). We also examined brain tissue because it undergoes profound changes during the early fetal stages, such as cell proliferation, differentiation and migration. Kv1.3 localizes to the central and peripheral nervous systems, while Kv1.5 overlaps mostly with the central nervous system (Bielanska et al., 2010). In summary, we concluded that Kv1.3 and Kv1.5 channels followed a differential developmental expression profile, which eventually defines an adult phenotype and influences final physiological functions (Roberds and Tamkun, 1991; Lesage et al., 1992).

\section{THE ROLE OF Kv1.3 AND Kv1.5 IN CELL PROLIFERATION}

Accumulating evidence suggests that many drugs and toxins that specifically block the activity of $\mathrm{Kv}$ channels decrease cell proliferation (Amigorena et al., 1990; Day et al., 1993; Wonderlin and Strobl, 1996; Chittajallu et al., 2002; Conti, 2004; Pardo, 2004; Kunzelmann, 2005; Felipe et al., 2006; Arcangeli et al., 2009; Wulff et al., 2009). For example, non-specific $\mathrm{K}^{+}$channel blockers such as 4-AP, TEA and quinidine exert anti-proliferative effects in several different mammalian cell models (Mauro et al., 1997; Hoffman et al., 1998; Liu et al., 1998; Vaur et al., 1998; Wohlrab and Markwardt, 1999; Faehling et al., 2001; Wohlrab et al., 2002; Roderick et al., 2003).

Although the underlying mechanisms regarding how these channels promote proliferation is still a subject of debate (RouraFerrer et al., 2008; Villalonga et al., 2008), there are several events that may be controlled by $\mathrm{Kv}$ during cell growth, including membrane potential, $\mathrm{Ca}^{2+}$ signaling and cell volume (Wonderlin and Strobl, 1996; Conti, 2004; Pardo, 2004; Felipe et al., 2006). For example, during the early phases of cell cycle progression (G1/S), cells undergo a transient hyperpolarization which involves Kv channel activity (Wonderlin and Strobl, 1996). Interestingly, cancer cells are typically more depolarized in comparison with terminally differentiated cells (Pardo, 2004; O'Grady and Lee, 2005), although a transient hyperpolarization is required for the progression of the early G1 phase of the cell cycle (Wonderlin and Strobl, 1996). Thus, one would hypothesize that a blockage of $\mathrm{K}^{+}$flux, which would lead to depolarization, 
should interfere with cell proliferation by inhibiting transient hyperpolarization.

Conversely, during lymphocyte proliferation, The combined action of $\mathrm{Kv} 1.3$ and $\mathrm{KCa} 1$ provides enough hyperpolarization to allow the $\mathrm{Ca}^{2+}$ influx required for proliferation. The resultant negative shift in membrane potential generates the required driving force for $\mathrm{Ca}^{2+}$ entry through $\mathrm{Ca}^{2+}$ channels (CRAC) from the extracellular space and its release from the inner stores (Arcangeli et al., 2009). Furthermore, cell growth is associated with cell volume increases throughout the G1 phase of the cell cycle (Lang et al., 2000). In fact, glioma cells exhibit their highest proliferation rates within a relatively narrow range of cell volumes, with decreased proliferation both over and under this optimal range. So, the rate of cell proliferation it is optimal within a cell volume window and appears to be controlled by low and high cell size checkpoints (Rouzaire-Dubois et al., 2004). Changes in membrane potential and cell volume are necessary for cell cycle progression, both of which require the action of $\mathrm{K}^{+}$channels (Pardo, 2004).

The role of $\mathrm{Kv}$ channels in cell growth has been extensively studied in cells of the immune system. For instance, Kv1.3 is known to play an essential function in the activation of T lymphocytes (Panyi, 2005), which is dependent upon an increase in voltage-gated $\mathrm{K}^{+}$conductance (McCormack et al., 1999). Moreover, a selective inhibition of Kv1.3 channels prevents cell activation and has been shown to exhibit immunosuppressive effects (Shah et al., 2003). Although previous studies have argued against a role of Kv1.3 in proliferation and activation of B-lymphocytes (Amigorena et al., 1990; Partiseti et al., 1993), it has been published that Kv1.3 protein levels increase in proliferating hippocampal microglia and control macrophage proliferation (Kotecha and Schlichter, 1999; Vicente et al., 2003; Villalonga et al., 2007a,b). Kv1.5 channels also play a crucial role in the activation and proliferation of oligodendrocytes, hippocampal microglia, macrophages and myoblasts (Attali et al., 1997; Kotecha and Schlichter, 1999; Villalonga et al., 2007a,b, 2008, 2010a,b). In macrophages, Kv1.3 depletion impairs cell growth and migration, both of which are characteristic features of cancer development (Villalonga et al., 2010a,b). Recently, we have determined that Kv1.5 is involved in the proliferation and migration of human B-cells (Vallejo-Gracia et al., 2013).

Several studies have demonstrated that Kv1.5 channels play a definitive role in muscle cell signaling. In this context, we have reported that regulation of Kv1.3 and Kv1.5 expression is cell cycle-dependent in L6E9 myoblasts. In fact, Kv1.5 expression changes throughout cell cycle progression with maximum expression occurring during the G1/S phase (Villalonga et al., 2008) and increased expression has also been noted during myogenesis (Vigdor-Alboim et al., 1999). Furthermore, our pharmacological evidence implies a role for Kv1.5 in the cell proliferation process (Villalonga et al., 2008). An alternative theory suggests that the role of the Kv1.3 channel in skeletal muscle could be connected to insulin sensitivity ( $\mathrm{Xu}$ et al., 2004). However, Kv1.5 is thought to inhibit skeletal muscle cell proliferation through a mechanism involving the accumulation of cyclin-dependent kinase inhibitors (such as p21 $1^{\text {cip-1 }}$ and p27kip1) and a marked decrease in the expression of cyclins A and D1 (Villalonga et al., 2008).
It is well established that glial cells abundantly express Kv channels, including those that are part of the Shaker (Kv1) subfamily (Verkhratsky and Steinhauser, 2000), and different Kv channels are closely related to the cell cycle progression of human glia (Sontheimer, 1994). For instance, in rat oligodendrocyte precursor cells, the transition of quiescent cells into the G1 phase of the cell cycle is accompanied by increased levels of Kv1.3 and Kv1.5 proteins (Chittajallu et al., 2002). Moreover, the specific inhibition of Kv1.3 elicited a G1 arrest, while a reduction in Kv1.5 protein mediated by antisense oligonucleotide transfection had no effect on cell growth (Attali et al., 1997; Chittajallu et al., 2002). In contrast, Kv1.5 antisense treatment inhibited cell growth in astrocytes (MacFarlane and Sontheimer, 2000). Because blockage of Kv1.5 sufficiently decreased the proliferation of astrocytes but not oligodendrocytes, this channel may play different functional roles in different types of cells. In fact, these differential results, together with the involvement of Kv1.5 in cell growth (Attali et al., 1997; MacFarlane and Sontheimer, 2000; Soliven et al., 2003; Wang, 2004; Lan et al., 2005; Villalonga et al., 2008), argue against a singular role for these channels in cell proliferation. In addition, both Kv1.3 and Kv1.5 have been shown to be involved in promoting apoptosis. Psora-4, PAP-1 and clofazimine, three distinct membrane-permeable inhibitors of Kv1.3, induce cell death by directly targeting the mitochondrial channel in multiple human and mouse cancer cell lines (Leanza et al., 2012) and efficiently induce apoptosis of chronic lymphocytic leukemia cells (Leanza et al., 2013).

There is no clear understanding how $\mathrm{K}^{+}$channels actually promote cell proliferation but possible mechanisms such as membrane voltage changes, cell volume regulation and the effect of mitogenic signals have been proposed (Wonderlin and Strobl, 1996). Exists a correlation between membrane potential and mitotic activity. Thus, terminally differentiated cells in G0 phase are very hyperpolarized whereas rapidly cycling tumor cells never entering G0 and are very depolarized (Binggeli and Weinstein, 1986). Mitogenic stimulation induces a short hyperpolarization at early G1, followed by depolarization. Although subsequent hyperpolarization during G1 has not been reported for all cell types, it is frequently observed and is believed to be essential for proliferation. Changes in membrane potential also alters the $\left[\mathrm{Ca}^{2+}\right]_{\mathrm{i}}$ concentration and promotes nutrient transport. Cell growth (increase in cell size) and proliferation (increase in number) are also closely related processes (Rouzaire-Dubois and Dubois, 1998). Thus, during progression through the cell cycle, the cell volume continuously changes. Particularly during G1/S transition and around the $\mathrm{M}$ phase large volume changes occur. It affects the concentration of enzymes that controls cell growth. Alteration in cell volume also regulate concentration of nutrients as well as cell-cycle effectors. Finally, cell cycle is controlled by distinct effectors such as oscillating cyclins and cyclindependent kinases. Inhibition of $\mathrm{K}^{+}$currents causes membrane depolarization and accumulation of the cyclin-dependent kinase inhibitors p27 and p21 (Ghiani et al., 1999). Thus, cell cyclerelevant proteins may be directly regulated by membrane voltage. Current evidence points that voltage-sensitive $\mathrm{K}^{+}$channels control cancer cell proliferation but the pathways involved are still unclear. 
Same channels can participate in the stimulation of both cell proliferation and apoptosis. This paradox may depend on the temporal pattern of $\mathrm{K}^{+}$channel activation. Thus, oscillating $\mathrm{K}^{+}$ channel activity typical of proliferating cells has completely different effects as sustained $\mathrm{K}^{+}$channel activation typical of apoptotic cells. Activation of $\mathrm{K}^{+}$channels during apoptosis is much more pronounced than during proliferation causing a drastic fall in the $\left[\mathrm{K}^{+}\right]_{i}$ compared to during cell cycling (Cain et al., 2001; Bock et al., 2002). Since many of the growth-and mitosis-related enzymes require a minimal $\left[\mathrm{K}^{+}\right]_{\mathrm{i}}$, a loss of $\mathrm{K}^{+}$reduce the proliferative activity (Hughes et al., 1997; Bortner and Cidlowski, 1999; Cain et al., 2001; Bock et al., 2002). Therefore, activation of both $\mathrm{Cl}^{-}$and $\mathrm{K}^{+}$channels must stay within a certain conductance to support proliferation, otherwise programmed cell death is triggered (Bock et al., 2002). Another important factor could be in $\mathrm{Ca}^{2+}$ signaling. Oscillatory $\mathrm{Ca}^{2+}$ rises were associated with proliferation and have not been observed during apoptosis. In contrast, a steady $\mathrm{Ca}^{2+}$ increase appears to be needed for apoptotic enzymes activity (Kunzelmann, 2005).

\section{Kv1.3 AND Kv1.5 IN SOLID CANCERS}

In addition to their role in proliferation, migration and invasion (Conti, 2004; Pardo, 2004; Felipe et al., 2006; Villalonga et al., 2010a,b), potassium channels appear to contribute to the development of cancer (Kunzelmann, 2005). Kv channels are expressed in a number of tumors and cancer cell lines (Nilius and Wohlrab, 1992; Chin et al., 1997; Skryma et al., 1997; Laniado et al., 2001). Moreover, induced tumors in experimental models also exhibit high levels of several voltage-gated $\mathrm{K}^{+}$channels, including Kv1.3 and Kv1.5 (Villalonga et al., 2007a,b).

Over the past decade, many studies have found that these channels are aberrantly expressed in different human tumor cells (Table 1), and the expression of both Kv1.3 and Kv1.5 channels is altered in a variety of human cancers including prostate cancer (Abdul and Hoosein, 2002a,b, 2006), colon cancer (Abdul and Hoosein, 2002a,b), breast cancer (Abdul et al., 2003; Brevet et al., 2009; Liu et al., 2010), lung cancer (Pancrazio et al., 1993; Wang et al., 2002), liver cancer (Zhou et al., 2003), smooth muscle cancers (Bielanska et al., 2012a), skeletal muscle cancers (Bielanska et al., 2012b), kidney cancer, bladder cancer, skin cancers (Bielanska et al., 2009) and gliomas (Preußat et al., 2003).

The number of tumor cells diminishes when $\mathrm{K}^{+}$channels are blocked with toxins or drugs. For example, $\mathrm{K}^{+}$channel blockers exhibit anti-proliferative effects in several human cancers such as prostate tumors (Rybalchenko et al., 2001; Abdul and Hoosein, 2002a; Fraser et al., 2003), hepatocarcinoma (Zhou et al., 2003), mesothelioma (Utermark et al., 2003), colon cancer (Abdul and Hoosein, 2002b), breast carcinoma (Strobl et al., 1995; Abdul et al., 2003), glioma (Preußat et al., 2003), and melanoma (Nilius and Wohlrab, 1992; Allen et al., 1997; Artym and Petty, 2002).

\section{GASTROINTESTINAL CANCERS}

Many Kv channels, including Kv1.3, Kv1.5, Kv1.6, Kv2.1, and $\mathrm{Kv} 2.2$, are present in immortalized gastric epithelial cells and several gastric cancer cells (AGS, KATOIII, MKN28, MKN45, MGC803, SGC7901, SGC7901/ADR, and SGC7901/VCR). Interestingly, downregulation of Kv1.5 significantly inhibits cell proliferation and the tumorigenicity of SGC7901 cells. However, the authors conclude that Kv1.5 is necessary, but not sufficient, for gastric cancer cell proliferation (Lan et al., 2005). In addition, siRNA-mediated depletion of Kv1.5 abolished the depolarization-induced influx of $\mathrm{Ca}^{2+}$. Thus, Kv1.5 channels may be involved in tumor cell proliferation by controlling $\mathrm{Ca}^{2+}$ entry. In addition, $\mathrm{I}_{\mathrm{Ks}}$ currents are related to the development of multi-drug resistance in gastric cancer cells (Wu et al., 2002). Therefore, these studies could provide a novel strategy to reverse the malignant phenotype of gastric cancer cells.

Proliferation of several human colon cancer cell lines (SW1116, LoVo, Colo320DM, and LS174t) was increased by two $\mathrm{K}^{+}$channel activators, minoxidil and diazoxide. In contrast, several Kv blockers, including dequalinium and amiodarone, caused a marked growth-inhibition of human colon cancer cell lines. Glibenclamide is another Kv channel blocker that inhibits cellular proliferation (Abdul and Hoosein, 2002a,b). Proliferation of the colorectal carcinoma cell line DLD- 1 is drastically reduced in the presence of 4-AP. However, inhibition of $\mathrm{Ca}^{2+}$-sensitive $\mathrm{K}^{+}$channels and ATP-sensitive $\mathrm{K}^{+}$channels did not have an effect on cell proliferation. Interestingly, $\mathrm{K}^{+}$channel inhibitors blocked $\left[\mathrm{Ca}^{2+}\right]_{\mathrm{i}}$ influx, suggesting that $\mathrm{K}^{+}$channel activity may control the proliferation of colon cancer cells by modulating $\mathrm{Ca}^{2+}$ entry (Yao and Kwan, 1999). Although colon biopsies exhibited an increase in Kv1.3 and Kv1.5 expression, this phenomenon may be an artifact of the massive presence of inflammatory cells, which express high levels of both channels (Bielanska et al., 2009).

\section{BREAST CANCER}

Kv1.3 expression has been examined by immunohistochemistry in healthy human breast samples and their matched cancer tissue counterparts. While $\mathrm{Kv}$ immunostaining is not observed in normal human breast tissues, most cancer specimens show moderate staining in the epithelial compartment. In addition, the $\mathrm{K}^{+}$channel activator minoxidil stimulates the growth of MCF-7 human breast cancer cells. On the contrary, $\mathrm{K}^{+}$channel blockers such as dequalinium and amiodarone have marked inhibitory effects on MCF-7 cell proliferation (Abdul et al., 2003). Other $\mathrm{K}^{+}$ channel-blockers also inhibit breast cancer growth (Strobl et al., 1995 ) and potentiate the growth-inhibitory effects of tamoxifen on human breast (MCF-7, MDA-MB-231), prostate (PC3, MDAPCA-2B), and colon (Colo320DM, SW1116) cancer cell lines (Abdul et al., 2003). However, the expression of Kv1.3 in breast cancer is not well defined. Kv1.3 expression is increased in breast cancer biopsies in comparison with healthy breast tissues (Abdul et al., 2003). However, Brevet et al. argues that less Kv1.3 expression is found in cancerous samples, and claims that Kv1.3 gene promoter methylation is increased. Because Kv1.3 expression correlates with both poorly differentiated tumors and a younger age of patients with tumors, the authors suggest that a loss of Kv1.3 may be a marker for poor prognosis of breast tumors (Brevet et al., 2009). Immortalized human mammary epithelial cells with different tumorigenic properties demonstrated that the expression of Kv1.3 varies depending on the tumorigenicity and stage of the breast cancer (Jang et al., 2009). In addition, we have recently found that Kv1.3 and Kv1.5 expression increases concomitantly with an elevation of infiltrating inflammatory cells surrounding 
Table 1 | Expression of Kv1.3 and Kv1.5 in solid cancers and tumoral cells.




Table 1 | Continued

\begin{tabular}{|c|c|c|c|c|c|}
\hline Tissues & Tumors and cell lines & Features & Kv1.3 & Kv1.5 & References \\
\hline Pancreas & Pancreas adenocarcinoma & $\begin{array}{l}\text { Positive in infiltrating } \\
\text { inflammatory cells }\end{array}$ & Absent & Moderate $(90 \%)$ & Bielanska et al., 2009 \\
\hline Ovary & & $\begin{array}{l}\text { Positive in infiltrating } \\
\text { inflammatory cells }\end{array}$ & Absent & Absent & Bielanska et al., 2009 \\
\hline Skin & Squamous skin cell carcinoma & N.A. & Absent & High (100\%) & Bielanska et al., 2009 \\
\hline
\end{tabular}

Parenthesis indicates the percentage of expressing cells. ${ }^{*}$ Expression compared to healthy and control samples. N.D, not determined; N.A, not available.

the tumor nodule in breast carcinoma samples (Bielanska et al., 2009). This finding could shed light on the debate, however, more studies must be undertaken to elucidate these mechanisms.

\section{PROSTATE CANCER}

Expression of Kv1.3 and Kv1.5 channels has also been extensively studied in prostate cancer cells. Four different human prostate cancer (Pca) cell lines, two of which were androgen-unresponsive (PC3, DU145) and two of which were androgen-responsive (MDA-PCA-2B, LNCaP), were examined by immunohistochemistry to determine expression levels of Kv1.3. Strong immunostaining for Kv1.3 was detected in normal prostate samples, whereas most of the Pca specimens showed strong and moderate Kv1.3 staining (Abdul and Hoosein, 2002a). In addition, different $\mathrm{K}^{+}$channel activators, such asminoxidil, 1-ethyl-2-benzimidazolinone, and diazoxide, had significant growth-stimulatory effects on PC3 cells. In contrast, $\mathrm{K}^{+}$ channel-blockers such as dequalinium, amiodarone, and glibenclamide, caused a dose-dependent growth inhibition of both androgen-unresponsive and androgen-responsive Pca cell lines. Furthermore, channel blockers triggered morphological feature changes such as nuclear shrinkage and fragmentation, suggesting an activation of apoptotic signaling mechanisms (Abdul and Hoosein, 2002a). Although the highly metastatic PC3 cell line expressed Kv1.3 (Laniado et al., 2001), its expression was inversely related to metastasis in prostate cancer (Abdul and Hoosein, 2002a). In another report, Kv density inversely correlated with the metastasis of human prostate cancer cell lines (Laniado et al., 2001). Thus, lower Kv-staining in clinical Pca specimens compared to $\mathrm{Kv}$-staining levels in normal prostate cells may correlate with an increased probability of metastatic disease (Abdul and Hoosein, 2002a). Voltage-gated $\mathrm{K}^{+}$currents have been characterized by electrophysiology in rat (Mat-LyLu and AT-2) and human (PC3 and LNCaP) PCa cell lines (Skryma et al., 1997; Rane, 2000; Laniado et al., 2001; Rybalchenko et al., 2001). Both the strongly metastatic MAT-LyLu and the weakly metastatic AT-2 cell lines expressed Kv1.3 currents. Interestingly, Kv1.3 currents had different biophysical properties in the two rat prostate cancer cell lines, which displayed markedly different metastatic abilities. Thus, MAT-LyLu cells displayed significantly smaller maximal $\mathrm{K}^{+}$ current densities and an increased negative resting potential when compared to AT-2 cells. Taken together, these data suggest that $\mathrm{K}^{+}$ currents in the MAT-LyLu cells may be less active than those in the AT-2 cells (Fraser et al., 2000). Therefore, human prostate cancer cells with different metastatic ability displayed a differential modulatory action of $\mathrm{K}^{+}$channels. This finding, together with the exclusive expression of voltage-gated $\mathrm{Na}^{+}$channels in MAT-LyLu cells (Grimes et al., 1995), suggests a role for voltage-dependent ion channels in metastatic cell behavior (Laniado et al., 1997; Fraser et al., 2003). High epithelial Kv1.3 expression has also been observed in all normal prostate and benign prostatic hyperplasias $(\mathrm{BPH})$, whereas only half of primary human prostate cancer (Pca) samples express Kv1.3. Furthermore, reduced Kv1.3 protein levels in Pca correlated with high tumor grade and a poor prognosis. Because there was a significant inverse correlation between Kv1.3 levels and prostate tumor stage, Kv1.3 expression may be a useful diagnostic or prognostic marker for prostate cancer (Abdul and Hoosein, 2006).

\section{MUSCLE SARCOMAS}

$\mathrm{Kv}$ channels are crucial for the modulation of arterial tone and the control of vascular smooth muscle cell proliferation (Michelakis et al., 1997) and migration (Cidad et al., 2010; Cheong et al., 2011). Although myofibers are terminally differentiated, some myoblasts may proliferate by re-entering the cell cycle. Margatoxin, a specific blocker of Kv1.3, reduces proliferation and migration of mouse and human vascular smooth muscle cells. However, margatoxin does not fully abrogate migration, suggesting that a Kv1.3-independent component is involved in this process (Cheong et al., 2011). During vascular smooth muscle proliferation, Kv1.3 expression increases while Kv1.5 expression decreases (Cidad et al., 2010). Thus, Kv1.3 expression is altered during myoblast proliferation and differentiation, although it does not play a substantial role in either process (Villalonga et al., 2008). Conversely, Kv1.5 channel expression seems to contribute to vascular smooth muscle tone (Yuan et al., 1998).

In a recent study, we analyzed Kv1.3 and Kv1.5 expression in human samples of smooth muscle tumors [such as leiomyoma (LM) and leiomyosarcoma (LMS)] and compared the tumor samples to their healthy specimen counterparts. LM and LMS are a benign uterus tumor and an aggressive retroperitoneal neoplasm, respectively. Kv1.3 is poorly expressed in healthy muscle and in indolent LM samples but was significantly induced in malignant LMS. Similar to Kv1.3, Kv1.5 is almost absent in healthy biopsies, but Kv1.5 staining was heterogeneous and faint in LM samples. In contrast, Kv1.5 displayed a poor and homogeneous expression in aggressive LMS samples. Interestingly, a clear positive correlation between the expression of Kv1.3 and Kv1.5 and the aggressiveness 
of the smooth muscle neoplasm was noted. These results suggested that Kv1.3 and Kv1.5 could be used as potential molecular targets for the treatment of aggressive smooth muscle sarcomas (Bielanska et al., 2012a,b).

Kv1.3 and Kv1.5 undergo alterations in different types of human skeletal muscle sarcomas (Bielanska et al., 2009, 2012b). $\mathrm{Kv} 1.3$ is absent in the less aggressive embryonal rhabdomyosarcoma (ERMS), whereas its expression in the aggressive alveolar rhabdomyosarcoma (ARMS) is notable and equivalent to that found in fetal muscle. Kv1.5, which weakly stains healthy adult skeletal muscle, strongly stains fetal tissues in a manner similar to that of Kv1.3. In addition, ERMS specimens show heterogeneous expression of Kv1.5, which could indicate different stages of proliferation and/or differentiation of individual cells. In contrast, ARMS samples express homogeneous and highly expressed levels of Kv1.5 (Bielanska et al., 2012b). Therefore, the expression of both Kv1.3 and Kv1.5 channels increased significantly with respect to the tumor aggressiveness grade in ERMS and ARMS.

\section{GLIOMAS}

In addition to contributing to the proliferation of normal glia, $\mathrm{Kv} 1.3$ is detected in human gliomas, which are brain tumors arising from glial cells. Gliomas emerge from both astrocytic and oligodendrocytic lineages and consist of low and high malignancy grades, respectively. Preußat and coworkers have reported that some Kv1.3 and Kv1.5 differential expression occurs with respect to the malignancy grade of the tumor. For example, Kv1.5 expression is elevated in astrocytomas, moderate in oligodendrogliomas, and low in glioblastomas. Although the expression of Kv1.5 inversely correlates with glioma malignancy, no such correlation is evident for Kv1.3. These data suggest that reduced levels of Kv1.5 protein in biopsies when compared to the levels found in adjacent healthy tissues may be a good candidate biomarker for both glioma detection and outcome prediction (Preußat et al., 2003). Other studies have revealed abundant Kv1.3 and Kv1.5 expression in brain tumors and suggested that while Kv1.3 expression is notable in astrocytomas, Kv1.5 expression is elevated in glioblastomas (Bielanska et al., 2009). Although it is not known whether Kv1.3 and Kv1.5 expression is increased in gliomas vs. healthy cells, Kv1.5 expression also occurred more in diffuse astrocytoma than in high grade ones. Moreover, glioblastoma patients with higher Kv1.5 expression had slightly better survival (Arvind et al., 2012).

\section{OTHER SOLID CANCERS}

Recently, we have performed an extensive analysis of Kv1.3 and Kv1.5 protein expression in a wide variety of human tumors. Our results indicated that most cancers experienced an alteration of $\mathrm{Kv}$ gene expression. We found that Kv1.3 is present in healthy stomach, kidney, skeletal muscle, and lymph node, whereas expression of Kv1.3 was low in the breast, ovary, pancreas, bladder, lung, colon, and brain. Taken together, these data demonstrated that Kv1.3 is more ubiquitously expressed than was suggested by previous studies. In addition, most tumors showed no major differences in Kv1.3 expression when compared to healthy tissues. However, Kv1.3 expression was downregulated in kidney, bladder, and lung carcinomas (Bielanska et al., 2009). On the other hand, Kv1.5 expression was evident in most of the analyzed tissues but not in the breast. The abundance of Kv1.5 was low in the ovary, urinary bladder, and lung. Interestingly, unlike Kv1.3, Kv1.5 expression was increased in most human tumors. For example, stomach, pancreatic, and bladder tumors expressed more Kv1.5 than healthy specimens, however, Kv1.5 expression was decreased in renal adenocarcinoma when compared to healthy tissues. Because this channel is involved in $\mathrm{K}^{+}$transport and cell volume regulation (Felipe et al., 1993), a decrease in Kv1.5 expression would likely be accompanied by a loss of renal function. Finally, Kv1.5 expression was unaffected in ovary and lung tumors (Bielanska et al., 2009).

The immunohistochemical analysis of Kv1.3 and Kv1.5 channels in all of these cancers demonstrated that in most cases, stronger Kv1.3 and Kv1.5 expression is mainly confined to the inflammatory cells surrounding the tumors (Bielanska et al., 2009).

It is tempting to speculate that because these human specimens are usually from patients who have already been diagnosed with some type of cancer, most of them show histological signs of reactivity and should be interpreted with caution. This was the case for stomach, pancreatic, and breast cancers (Bielanska et al., 2009) and it may explain differences between our studies and those performed by Hoosein and coworkers in breast cancer (Abdul et al., 2003). Contrary to this hypothesis, other cancers such as those of the bladder, skin, ovary, and lymph node, exhibited Kv1.5 induction in the tumorigenic cells (Bielanska et al., 2009).

\section{Kv1.3 AND Kv1.5 IN BLO0D CANCERS LYMPHOMAS}

Because Kv channels control neoplastic processes in leukocytes such as cell activation, proliferation, migration and apoptosis (DeCoursey et al., 1984; Gollapudi et al., 1988; Khanna et al., 1999; Wickenden, 2002; Vicente et al., 2003, 2005; Cahalan and Chandy, 2009; Wulff et al., 2009), these proteins are thought to be involved in the mechanisms underlying lymphoma invasiveness (Cruse et al., 2006; Bielanska et al., 2009; Felipe et al., 2012) and malignancy.

In a preliminary study, we have shown that Kv1.3 and Kv1.5 are differentially altered in human non-Hodgkin's lymphomas (Bielanska et al., 2009), however, a more complete study was required to confirm these initial findings. Recently, we have examined the expression of Kv1.3 and Kv1.5 in a panel of human non-Hodgkin lymphomas. To our knowledge this was the first study to examine $\mathrm{Kv} 1.3$ and $\mathrm{Kv} 1.5$ expression in diffuse large B-cell, follicular B-cell, mantle, anaplastic and T-cell lymphomas in comparison with control lymph nodes. Furthermore, because these human cancers exhibited different grades of malignancy, we determined whether there was a correlative relationship between Kv1.3 and Kv1.5 expression and the clinical aggressiveness of these human lymphomas (Figure 1). Kv channels have previously been proposed as tumorigenic markers and therapeutic targets (Conti, 2004; Kunzelmann, 2005; Pardo et al., 2005; Felipe et al., 2006; Stuhmer et al., 2006), although in most cases there was no clear correlation between channel expression and tumorigenicity (Preußat et al., 2003). In these studies, we found that control 
lymph nodes expressed high levels of heterogeneous Kv1.3, which could indicate a certain mechanism of action, while Kv1.5 abundance was low and homogeneous. Interestingly, Kv1.3 and Kv1.5 were differentially altered in non-Hodgkin's human lymphomas. For example, indolent follicular lymphomas expressed noticeable levels of Kv1.5, while aggressive diffuse large B cell lymphomas showed low Kv1.5 expression. Thus, Kv1.5 expression is inversely correlated with clinical aggressiveness in non-Hodgkin's lymphomas. Preußat and coworkers found a similar inverse correlation between the level of Kv1.5 immunostaining and tumor grade in gliomas (Preußat et al., 2003). Although further studies with a larger number of subjects for each tumor type must be performed, the level of Kv1.5 protein may be useful in the diagnosis or prognosis of some lymphomas (Table 2).

In contrast, the expression of Kv1.3, did not correlate with either the state of de-differentiation or the nature of the lymphomas, although its expression was decreased in most cancers (Bielanska et al., 2009) (Figure 1). Previous studies have also demonstrated that Kv1.3 expression showed no apparent connection with the tumorigenic state when considering the prognosis

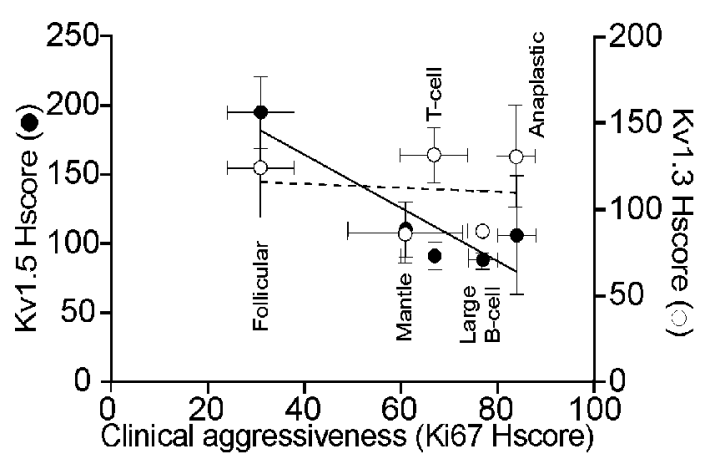

FIGURE 1 | Expression of Kv1.3 and Kv1.5 in human non-Hodgkin lymphomas. A Histoscore (Hscore) was calculated to establish a phenotypical correlation of clinical agressiveness based in the expression of Ki67 (Castellvi et al., 2009). (o) Kv1.3 Hscore in non-Hodgkin's lymphomas. (•) Kv1.5 Hscore. Results are mean \pm SEM of Kv1.3 and Kv1.5 Hscore plotted against Ki67 Hscore as a marker of the clinical aggressiveness of the lymphoma. While a Pearson's correlation coefficient of $r=0.106$ with a $P<0.866$ indicated a complete absence of correlation of Kv1.3, a Pearson's correlation coefficient of $r=0.895$ with a $P<0.040$ indicated an inverse correlation between Kv1.5 abundance and the aggressiveness of tumor. of the tumor (Arcangeli et al., 2009; Bielanska et al., 2009). Kv1.3 expression showed no apparent correlation with malignancy or clinical aggressiveness, similar to the findings in gliomas (Preußat et al., 2003). Taken together, these data suggest that Kv1.3 may act as a tumor suppressor. Hypoxia, which occurs commonly in solid tumors and is associated with malignant progression (Vaupel et al., 2004), decreased Kv1.3 protein levels and activity in human T lymphocytes (Conforti et al., 2003). Moreover, suppression of Kv1.3 prevents apoptosis, which would favor tumor development (Bonnet et al., 2007).

\section{LEUKEMIAS}

Distinct $\mathrm{K}^{+}$channel blockers have anti-proliferative effects on human myeloblastic leukemia cells (Wang et al., 1997; Xu et al., 1999). Moreover, membrane-permeable $\mathrm{K}^{+}$channel inhibitors, such as Psora-4, PAP-1 and clofazimine, induce apoptosis of chronic lymphocytic leukemia cells. In contrast, these cells are resistant to the membrane-impermeable inhibitor ShK, which clearly suggests that the plasma membrane-located Kv1.3 is not responsible for the observed apoptotic response. In fact, pathologic B cells showed higher Kv1.3 protein expression and were sensitive to treatment, whereas healthy cells express less Kv1.3 and were resistant to the drugs (Leanza et al., 2013). Clofazimine treatment also significantly reduced tumor size in an orthotopic melanoma mouse model (Leanza et al., 2012). Therefore, clofazimine might be a promising new therapeutic tool to treat chronic lymphocytic leukemia patients (Leanza et al., 2013).

Because Kv1.3 expression was decreased in most cancers, some authors have suggested that this channel may act as a tumor suppressor. In this context, hypoxia decreased Kv1.3 protein levels and inhibited proliferation of T-lymphocytes (Conforti et al., 2003; Chandy et al., 2004; Vaupel et al., 2004). Surprisingly, the $\mathrm{Kv} 1.3$ channel is also thought to play an important role in apoptosis in T-cells (Arcangeli et al., 2009) because elevated Kv1.3 facilitates an apoptotic response (Bock et al., 2002; Szabo et al., 2008). Thus, it is thought that Kv1.3 promotes proliferation in oligodendrocytes (Vautier et al., 2004) but also controls leukocyte activation and is crucial for the induction of apoptosis in lymphocytes (Storey et al., 2003; Szabo et al., 2004, 2008, 2010; Gulbins et al., 2010). These interesting findings seem rather contradictory with respect to the cellular function of Kv1.3. However, it has been suggested that the environmental conditions in which channel activation takes place and the magnitude of the activated conductance could determine whether the channel supports

Table 2 | Expression of Kv1.3 and Kv1.5 in blood cancers.

\begin{tabular}{|c|c|c|c|c|c|}
\hline Tissue & Kv1.3 & Kv1.5 & Tumors and Cell lines & Features & References \\
\hline Lymph node & Low & High & Follicular B-cell lymphoma & Low aggressiveness non-Hodgkin's lymphoma & Vallejo-Gracia et al., 2013 \\
\hline Lymph node & Low & Low & Mantle Iymphoma & High aggressiveness non-Hodgkin's Iymphoma & Vallejo-Gracia et al., 2013 \\
\hline Lymph node & Low & Moderate & T-cell lymphoma & High aggressiveness non-Hodgkin's Iymphoma & Vallejo-Gracia et al., 2013 \\
\hline Lymph node & Moderate & Low & Diffuse large B-cell lymphoma & High aggressiveness non-Hodgkin's Iymphoma & Vallejo-Gracia et al., 2013 \\
\hline Lymph node & Low & Moderate & Anaplastic lymphoma & High aggressiveness non-Hodgkin's lymphoma & Vallejo-Gracia et al., 2013 \\
\hline Lymph node & High & N.D. & Chronic lymphocytic leukenia & & Leanza et al., 2013 \\
\hline
\end{tabular}

N.D, not determined. 
proliferation or apoptosis (Kunzelmann, 2005). In this context, it is tempting to speculate that suppression of Kv1.3 activity would slow apoptosis and favor tumor development. Moreover, increasing the expression of Kv1.5 with dichloroacetate triggers apoptosis in lung, breast, glioblastoma and endometrial cancer cell lines (Bonnet et al., 2007; Wong et al., 2008). Furthermore, the $\mathrm{K}^{+}$ channel blocker clofilium induces apoptosis in human promyelocytic leukemia (HL-60) cells (Choi et al., 1999). However, these hypotheses are supported by little evidence, and further research is required to confirm these conclusions.

\section{CONCLUSION}

Several $\mathrm{K}^{+}$channels are essential for cell proliferation and appear to play a role in the development of cancer. In this context, further investigation is needed to fully understand the role of membrane ion channels in normal and neoplastic cell proliferation. A large body of data indicates that tumor cells differentially altered the expression of voltage dependent $\mathrm{K}^{+}$ channels. Furthermore, Kv1.5 and to some extent Kv1.3, are aberrantly expressed in many human cancers. We can conclude that the abundance of Kv1.5 expression mostly increases in tumor cells, whereas Kv1.3 expression is generally downregulated. Interestingly, both Kv1.3 and Kv1.5 have displayed an

\section{REFERENCES}

Abdul, M., and Hoosein, N. (2002a). Expression and activity of potassium ion channels in human prostate cancer. Cancer Lett. 186, 99-105. doi: 10.1016/S0304-3835 (02)00348-8

Abdul, M., and Hoosein, N. (2002b). Voltage-gated potassium ion channels in colon cancer. Oncol. Rep. 9, 961-964. doi: 10.1016/S0304-3835 (02)00348-8

Abdul, M., and Hoosein, N. (2006). Reduced Kv1.3 potassium channel expression in human prostate cancer. J. Membr. Biol. 214, 99-102. doi: 10.1007/s00232-006-0065-7

Abdul, M., Santo, A., and Hoosein, N. (2003). Activity of potassium channel-blockers in breast cancer. Anticancer Res. 23, 3347-3351.

Allen, D. H., Lepple-Wienhues, A., and Cahalan, M. D. (1997). Ion channel phenotype of melanoma cell lines. J. Membr. Biol. 155, 27-34. doi: 10.1007/s002329900155

Amigorena, S., Choquet, D., Teillaud, J. L., Korn, H., and Fridman, W. H. (1990). Ion channel blockers inhibit B cell activation at a precise stage of the G1 phase of the cell cycle. Possible involvement of $\mathrm{K}+$ channels. J. Immunol. 144, 2038-2045.

Arcangeli, A., Crociani, O., Lastraioli, E., Masi, A., Pillozzi, S., and Becchetti, A. (2009). Targeting ion channels in cancer: a novel frontier in antineoplastic therapy. Curr.
Med. Chem. 16, 66-93. doi: 10. 2174/092986709787002835

Artym, V. V., and Petty, H. R. (2002). Molecular proximity of Kv1.3 voltage-gated potassium channels and beta(1)-integrins on the plasma membrane of melanoma cells: effects of cell adherence and channel blockers. J. Gen. Physiol. 120, 29-37. doi: 10.1085/jgp.20028607

Arvind, S., Arivazhagan, A., Santosh, V., and Chandramouli, B. A. (2012). Differential expression of a novel voltage gated potassium channel$\mathrm{Kv} 1.5$ in astrocytomas and its impact on prognosis in glioblastoma. Br. J. Neurosurg. 26, 16-20. doi: 10.3109/02688697.2011.583365

Ashcroft, F. M. (2000). Ion Channels and Disease: Channelopathies. San Diego, CA: Academic Press.

Attali, B., Wang, N., Kolot, A., Sobko, A., Cherepanov, V., and Soliven, B. (1997). Characterization of delayed rectifier $\mathrm{Kv}$ channels in oligodendrocytes and progenitor cells. J. Neurosci. 17, 8234-8245.

Beeton, C., Pennington, M. W., Wulff, H., Singh, S., Nugent, D., Crossley, G., et al. (2005). Targeting effector memory $\mathrm{T}$ cells with a selective peptide inhibitor of Kv1.3 channels for therapy of autoimmune diseases. Mol. Pharmacol. 67, 1369-1381. doi: 10.1124/mol.104.008193

Bielanska, J., Hernandez-Losa, J., Moline, T., Somoza, R., Cajal, S. R., Condom, E., et al. (2012a). Increased voltage-dependent $\mathrm{K}(+)$

apparent connection between their expression and the tumorigenic state of different cancer cells that may be attributable to remodeling mechanisms. To date we know that there is a clear positive correlation between the expression of both Kv1.3 and Kv1.5 channels and the clinical aggressiveness of smooth muscle neoplasms. In contrast, an inverse correlation between the levels of Kv1.3 and prostate cancer tumor stage/metastatic capacity and an inverse correlation between Kv1.5 expression and glioma tumor grade have been described. In addition, Kv1.5 expression exhibits a significant correlation with the degree of malignancy of rhabdomyosarcomas, renal tumors and lymphomas. These findings suggest that Kv1.3 and Kv1.5 channels could be used not only as tumor biomarkers but also as prognostic and diagnostic indicators.

\section{ACKNOWLEDGMENTS}

The work carried out by the Molecular Physiology Laboratory was funded by grants from Ministerio de Economía y Competitividad (MINECO), Spain (BFU2008-00431, BFU2011-23268 and CSD2008-00005). The Molecular Physiology Laboratory would like to acknowledge all past members who have contributed to this research. The editorial assistance of the American Journal Experts is also acknowledged.

channel Kv1.3 and Kv1.5 expression correlates with leiomyosarcoma aggressiveness. Oncol Lett. 4, 227-230.

Bielanska, J., Hernandez-Losa, J., Moline, T., Somoza, R., Ramon y Cajal, S., Condom, E., et al. (2012b). Differential expression of Kv1.3 and Kv1.5 voltage-dependent $\mathrm{K}+$ channels in human skeletal muscle sarcomas. Cancer Invest. 30, 203-208. doi: 10.3109/07357907. 2012.654872

Bielanska, J., Hernandez-Losa, J., Moline, T., Somoza, R., Ramon, Y. C. S., Condom, E., et al. (2010). Voltage-dependent potassium channels Kv1.3 and Kv1.5 in human fetus. Cell Physiol. Biochem. 26, 219-226. doi: 10.1159/000320528

Bielanska, J., Hernandez-Losa, J., PerezVerdaguer, M., Moline, T., Somoza, R., Ramon, Y. C. S., et al. (2009). Voltage-dependent potassium channels Kv1.3 and Kv1.5 in human cancer. Curr. Cancer Drug Targets. 9, 904-914. doi: 10.2174/15680090 9790192400

Binggeli, R., and Weinstein, R. C. (1986). Membrane potentials and sodium channels: hypotheses for growth regulation and cancer formation based on changes in sodium channels and gap junctions. J. Theor. Biol. 123, 377-401. doi: 10.1016/S0022-5193(86)80209-0

Bock, J., Szabo, I., Jekle, A., and Gulbins, E. (2002). Actinomycin D-induced apoptosis involves the potassium channel Kv1.3. Biochem. Biophys. Res. Commun. 295, 526-531. doi: 10.1016/S0006291X(02)00695-2

Bonnet, S., Archer, S. L., AllalunisTurner, J., Haromy, A., Beaulieu, C., Thompson, R., et al. (2007). A mitochondria- $\mathrm{K}^{+}$channel axis is suppressed in cancer and its normalization promotes apoptosis and inhibits cancer growth. Cancer Cell. 11, 37-51. doi: 10.1016/j.ccr.2006. 10.020

Bortner, C. D., and Cidlowski, J. A. (1999). Caspaseindependent/dependent regulation of $\mathrm{K}+$, cell shrinkage, and mitochondrial membrane potential during lymphocyte apoptosis. J. Biol. Chem. 274, 21953-21962. doi: 10.1074/jbc.274.31.21953

Brevet, M., Haren, N., Sevestre, H., Merviel, P., and Ouadid-Ahidouch, H. (2009). DNA methylation of $\mathrm{K}(\mathrm{v}) 1.3$ potassium channel gene promoter is associated with poorly differentiated breast adenocarcinoma. Cell. Physiol. Biochem. 24, 25-32. doi: 10.1159/000227810

Cahalan, M. D., and Chandy, K. G. (1997). Ion channels in the immune system as targets for immunosuppression. Curr. Opin. Biotechnol. 8, 749-756. doi: 10.1016/S0958-1669 (97)80130-9

Cahalan, M. D., and Chandy, K. G. (2009). The functional network of ion channels in $\mathrm{T}$ lymphocytes. Immunol. Rev. 231, 59-87. 
doi: $\quad$ 10.1111/j.1600-065X.2009. 00816.x

Cahalan, M. D., Wulff, H., and Chandy, K. G. (2001). Molecular properties and physiological roles of ion channels in the immune system. J. Clin. Immunol. 21, 235-252. doi: 10.1023/A:1010958907271

Cain, K., Langlais, C., Sun, X. M., Brown, D. G., and Cohen, G. M. (2001). Physiological concentrations of $\mathrm{K}+$ inhibit cytochrome c-dependent formation of apoptosome. J. Biol. Chem. 276, 41985-41990. doi: 10.1074/jbc. M107419200

Castellvi, J., Garcia, A., Ruiz-Marcellan, C., Hernandez-Losa, J., Peg, V., Salcedo, M., et al. (2009). Cell signaling in endometrial carcinoma: phosphorylated 4E-binding protein-1 expression in endometrial cancer correlates with aggressive tumors and prognosis. Hum. Pathol. 40, 1418-1426. doi: $10.1016 / \mathrm{j}$. humpath.2008.12.019

Caterall, W., Chandy, G., and Gutman, G. (2002). The IUPHAR Compendium of Voltage-Gated Ion Channels. Leeds: IUPHAR Media.

Cidad, P., Moreno-Dominguez, A., Novensa, L., Roque, M., Barquin, L., Heras, M., et al. (2010). Characterization of ion channels involved in the proliferative response of femoral artery smooth muscle cells. Arterioscler. Thromb. Vasc. Biol. 30, 1203-1211. doi: 10.1161/ATVBAHA.110.205187

Coma, M., Vicente, R., Busquets, S., Carbo, N., Tamkun, M. M., LopezSoriano, F. J., et al. (2003). Impaired voltage-gated $\mathrm{K}+$ channel expression in brain during experimental cancer cachexia. FEBS Lett. 536, 45-50. doi: 10.1016/S00145793(03)00009-7

Coma, M., Vicente, R., Tsevi, I., Grande, M., Tamkun, M. M., and Felipe, A. (2002). Different Kv2.1/Kv9.3 heteromer expression during brain and lung post-natal development in the rat. J. Physiol. Biochem. 58, 195-203. doi: 10.1007/ BF03179857

Conforti, L., Petrovic, M., Mohammad, D., Lee, S., Ma, Q., Barone, S., et al. (2003). Hypoxia regulates expression and activity of Kv1.3 channels in T lymphocytes: a possible role in T cell proliferation. J. Immunol. 170, 695-702.

Conti, M. (2004). Targeting K+ channels for cancer therapy. J. Exp. Ther. Oncol. 4, 161-166.

Cruse, G., Duffy, S. M., Brightling, C. E., and Bradding, P. (2006). Functional KCa3.1 K+ channels are required for human lung mast cell migration. Thorax 61, 880-885. doi: 10.1136/thx.2006.060319

Chandy, K. G., Wulff, H., Beeton, C., Pennington, M., Gutman, G. A., and Cahalan, M. D. (2004). K+ channels as targets for specific immunomodulation. Trends Pharmacol. Sci. 25, 280-289. doi: 10.1016/j.tips.2004. 03.010

Cheong, A., Li, J., Sukumar, P., Kumar, B., Zeng, F., Riches, K., et al. (2011). Potent suppression of vascular smooth muscle cell migration and human neointimal hyperplasia by KV1.3 channel blockers. Cardiovasc. Res. 89, 282-289. doi: 10.1093/cvr/cvq305

Chin, L. S., Park, C. C., Zitnay, K. M., Sinha, M., DiPatri, A. J. Jr., Perillan, P. et al. (1997). 4-Aminopyridine causes apoptosis and blocks an outward rectifier $\mathrm{K}+$ channel in malignant astrocytoma cell lines. J. Neurosci. Res. 48, 122-127. doi: 10. 1002/(SICI)1097-4547(19970415)4 8:2<122::AID-JNR4 > 3.3.CO;2-1

Chittajallu, R., Chen, Y., Wang, H., Yuan, X., Ghiani, C. A., Heckman, T., et al. (2002). Regulation of Kv1 subunit expression in oligodendrocyte progenitor cells and their role in G1/S phase progression of the cell cycle. Proc. Natl. Acad. Sci. U.S.A. 99, 2350-2355. doi: 10.1073/pnas.042698399

Choi, B. Y., Kim, H. Y., Lee, K. H., Cho, Y. H., and Kong, G. (1999). Clofilium, a potassium channel blocker, induces apoptosis of human promyelocytic leukemia (HL-60) cells via Bcl-2insensitive activation of caspase-3. Cancer Lett. 147, 85-93. doi: 10.1016/S0304-3835(99)00280-3

Day, M. L., Pickering, S. J., Johnson, M. H., and Cook, D. I. (1993). Cell-cycle control of a largeconductance $\mathrm{K}+$ channel in mouse early embryos. Nature 365, 560-562. doi: 10.1038/365560a0

Decher, N., Pirard, B., Bundis, F., Peukert, S., Baringhaus, K. H., Busch, A. E., et al. (2004). Molecular basis for Kv1.5 channel block: conservation of drug binding sites among voltage-gated $\mathrm{K}+$ channels. J. Biol. Chem. 279, 394-400. doi: 10.1074/jbc.M307411200

DeCoursey, T. E., Chandy, K. G., Gupta, S., and Cahalan, M. D. (1984). Voltage-gated K+ channels in human $\mathrm{T}$ lymphocytes: a role in mitogenesis? Nature 307, 465-468. doi: 10.1038/ $307465 \mathrm{a} 0$

Deutsch, C., and Lee, S. C. (1988). Cell volume regulation in lymphocytes. Ren. Physiol. Biochem. 11, 260-276.
Douglass, J., Osborne, P. B., Cai, Y. C., Wilkinson, M., Christie, M. J., and Adelman, J. P. (1990). Characterization and functional expression of a rat genomic DNA clone encoding a lymphocyte potassium channel. J. Immunol. 144, 4841-4850.

Du, Y. M., Zhang, X. X., Tu, D. N., Zhao, N., Liu, Y. J., Xiao, H., et al. (2010). Molecular determinants of Kv1.5 channel block by diphenyl phosphine oxide-1. J. Mol. Cell. Cardiol. 48, 1111-1120. doi: 10.1016/j.yjmcc.2010.02.010

Faehling, M., Koch, E. D., Raithel, J., Trischler, G., and Waltenberger, J. (2001). Vascular endothelial growth factor-A activates $\mathrm{Ca} 2+$-activated $\mathrm{K}+$ channels in human endothelial cells in culture. Int. J. Biochem. Cell. Biol. 33, 337-346. doi: 10.1016/S1357-2725(01)00021-8

Felipe, A., Bielanska, J., Comes, N., Vallejo, A., Roig, S., Ramon, Y. C. S., et al. (2012). Targeting the voltage-dependent $\mathrm{K}(+)$ channels Kv1.3 and Kv1.5 as tumor biomarkers for cancer detection and prevention. Curr. Med. Chem. 19, 661-674. doi: 10.2174/092986712798992048

Felipe, A., Knittle, T. J., Doyle, K. L., Snyders, D. J., and Tamkun, M. M. (1994). Differential expression of Isk mRNAs in mouse tissue during development and pregnancy. Am. J. Physiol. 267, C700-C705.

Felipe, A., Snyders, D. J., Deal, K. K., and Tamkun, M. M. (1993). Influence of cloned voltage-gated $\mathrm{K}+$ channel expression on alanine transport, $\mathrm{Rb}+$ uptake, and cell volume. Am. J. Physiol. 265, C1230-1238.

Felipe, A., Soler, C., and Comes, N. (2010). Kv1.5 in the immune system: the good, the bad, or the ugly? Front. Physiol. 1:152. doi: 10.3389/fphys.2010.00152

Felipe, A., Vicente, R., Villalonga, N., Roura-Ferrer, M., MartinezMarmol, R., Sole, L., et al. (2006). Potassium channels: new targets in cancer therapy. Cancer Detect. Prev. 30, 375-385. doi: 10.1016/j.cdp.2006.06.002

Fraser, S. P., Grimes, J. A., Diss, J. K., Stewart, D., Dolly, J. O., and Djamgoz, M. B. (2003). Predominant expression of Kv1.3 voltage-gated $\mathrm{K}+$ channel subunit in rat prostate cancer cell lines: electrophysiological, pharmacological and molecular characterisation. Pflugers Arch. 446, 559-571. doi: 10.1007/s00424-003-1077-0

Fraser, S. P., Grimes, J. A., and Djamgoz, M. B. (2000). Effects of voltage-gated ion channel modulators on rat prostatic cancer cell proliferation: comparison of strongly and weakly metastatic cell lines. Prostate 44, 61-76. doi: 10.10 02/1097-0045(20000615)44:1<61::A ID-PROS9>3.0.CO;2-3

Garcia-Calvo, M., Leonard, R. J., Novick, J., Stevens, S. P., Schmalhofer, W., Kaczorowski, G. J., et al., (1993). Purification, characterization, and biosynthesis of margatoxin, a component of Centruroides margaritatus venom that selectively inhibits voltagedependent potassium channels. J. Biol. Chem. 268, 18866-18874.

Ghiani, C. A., Yuan, X., Eisen, A. M., Knutson, P. L., DePinho, R. A., McBain, C. J., et al. (1999). Voltageactivated $\mathrm{K}+$ channels and membrane depolarization regulate accumulation of the cyclin-dependent kinase inhibitors p27(Kip1) and p21(CIP1) in glial progenitor cells. J. Neurosci. 19, 5380-5392.

Gollapudi, S. V., Vayuvegula, B. S., Thadepalli, H., and Gupta, S. (1988). Effect of $\mathrm{K}+$ channel blockers on anti-immunoglobulininduced murine B cell proliferation. J. Clin. Lab. Immunol. 27, 121-125.

Grande, M., Suarez, E., Vicente, R., Canto, C., Coma, M., Tamkun, M. M., et al. (2003). Voltage-dependent $\mathrm{K}+$ channel beta subunits in muscle: differential regulation during postnatal development and myogenesis. J. Cell. Physiol. 195, 187-193. doi: 10.1002/jcp.10203

Grimes, J. A., Fraser, S. P., Stephens, G. J., Downing, J. E., Laniado, M. E., Foster, C. S., et al. (1995). Differential expression of voltageactivated $\mathrm{Na}+$ currents in two prostatic tumour cell lines: contribution to invasiveness in vitro. FEBS Lett. 369, 290-294. doi: 10.1016/ 0014-5793(95)00772-2

Grissmer, S., Nguyen, A. N., Aiyar, J., Hanson, D. C., Mather, R. J., Gutman, G. A., et al. (1994). Pharmacological characterization of five cloned voltage-gated $\mathrm{K}+$ channels, types $\mathrm{Kv} 1.1,1.2,1.3,1.5$, and 3.1, stably expressed in mammalian cell lines. Mol. Pharmacol. 45, 1227-1234.

Grunnet, M., Rasmussen, H. B., Hay-Schmidt, A., and Klaerke, D. A. (2003). The voltage-gated potassium channel subunit, Kv1.3, is expressed in epithelia. Biochim. Biophys. Acta. 1616, 85-94. doi: 10. 1016/S0005-2736(03)00198-6

Gulbins, E., Sassi, N., Grassme, H., Zoratti, M., and Szabo, I. (2010). Role of Kv1.3 mitochondrial potassium channel in apoptotic 
signalling in lymphocytes. Biochim. Biophys. Acta. 1797, 1251-1259. doi: 10.1016/j.bbabio.2010.01.018

Hille, B. (2001). Ion Channels of Excitable Cells. 3rd Edn. Sunderland, MA: Sinauer Associates.

Hoffman, S., Gopalakrishna, R., Gundimeda, U., Murata, T., Spee, C., Ryan, S. J., et al. (1998). Verapamil inhibits proliferation, migration and protein kinase $\mathrm{C}$ activity in human retinal pigment epithelial cells. Exp. Eye Res. 67, 45-52. doi: 10.1006/exer.1998.0491

Hughes, F. M. Jr., Bortner, C. D., Purdy, J. A., and Cidlowski, J. A. (1997). Intracellular $\mathrm{K}+$ suppresses the activation of apoptosis in lymphocytes. J. Biol. Chem. 272, 30567-30576. doi: 10.1074/jbc.272.48.30567

Itoh, K., Stevens, B., Schachner, M., and Fields, R. D. (1995). Regulated expression of the neural cell adhesion molecule $\mathrm{L} 1$ by specific patterns of neural impulses. Science 270, 1369-1372. doi: 10.1126/science. 270.5240 .1369

Jang, S. H., Kang, K. S., Ryu, P. D., and Lee, S. Y. (2009). Kv1.3 voltage-gated $\mathrm{K}(+)$ channel subunit as a potential diagnostic marker and therapeutic target for breast cancer. BMB Rep. 42, 535-539. doi: 10.5483/BMBRep.2009.42.8.535

Khanna, R., Chang, M. C., Joiner, W. J., Kaczmarek, L. K., and Schlichter, L. C. (1999). hSK4/hIK1, a calmodulin-binding $\mathrm{KCa}$ channel in human $\mathrm{T}$ lymphocytes. Roles in proliferation and volume regulation. J. Biol. Chem. 274, 14838-14849. doi: 10.1074/jbc. 274 . 21.14838

Kotecha, S. A., and Schlichter, L. C. (1999). A Kv1.5 to Kv1.3 switch in endogenous hippocampal microglia and a role in proliferation. J. Neurosci. 19, 10680-10693.

Kunzelmann, K. (2005). Ion channels and cancer. J. Membr. Biol. 205, 159-173. doi: 10.1007/s00232-0050781-4

Kupper, J., Bowlby, M. R., Marom, S., and Levitan, I. B. (1995). Intracellular and extracellular amino acids that influence C-type inactivation and its modulation in a voltage-dependent potassium channel. Pflugers Arch. 430, 1-11. doi: 10.1007/BF00373833

Lan, M., Shi, Y., Han, Z., Hao, Z., Pan, Y., Liu, N., et al. (2005). Expression of delayed rectifier potassium channels and their possible roles in proliferation of human gastric cancer cells. Cancer Biol. Ther. 4, 1342-1347. doi: 10.4161/cbt.4. 12.2175
Lang, F., Ritter, M., Gamper, N., Huber, S., Fillon, S., Tanneur, V., et al. (2000). Cell volume in the regulation of cell proliferation and apoptotic cell death. Cell. Physiol. Biochem. 10, 417-428. doi: 10.1159/ 000016367

Laniado, M. E., Fraser, S. P., and Djamgoz, M. B. (2001). Voltagegated $\mathrm{K}(+)$ channel activity in human prostate cancer cell lines of markedly different metastatic potential: distinguishing characteristics of PC-3 and LNCaP cells. Prostate 46, 262-274. doi: 10. 1002/1097-0045(20010301)46:4<2 $62:: A I D-P R O S 1032>3.0 . C O ; 2-F$

Laniado, M. E., Lalani, E. N., Fraser, S. P., Grimes, J. A., Bhangal, G., Djamgoz, M. B., et al. (1997). Expression and functional analysis of voltage-activated $\mathrm{Na}+$ channels in human prostate cancer cell lines and their contribution to invasion in vitro. Am. J. Pathol. 150, 1213-1221.

Leanza, L., Henry, B., Sassi, N., Zoratti, M., Chandy, K. G., Gulbins, E., et al. (2012). Inhibitors of mitochondrial Kv1.3 channels induce Bax/Bakindependent death of cancer cells. EMBO Mol. Med. 4, 577-593. doi: 10.1002/emmm.201200235

Leanza, L., Trentin, L., Becker, K. A., Frezzato, F., Zoratti, M., Semenzato, G., et al. (2013). Clofazimine, Psora-4 and PAP-1, inhibitors of the potassium channel Kv1.3, as a new and selective therapeutic strategy in chronic lymphocytic leukemia. Leukemia 27, 1782-1785. doi: 10.1038/leu.2013.56

Leonard, R. J., Garcia, M. L., Slaughter, R. S., and Reuben, J. P. (1992). Selective blockers of voltage-gated $\mathrm{K}^{+}$channels depolarize human $\mathrm{T}$ lymphocytes: mechanism of the antiproliferative effect of charybdotoxin. Proc. Natl. Acad. Sci. U.S.A. 89, 10094-10098. doi: 10.1073/pnas. 89.21.10094

Lesage, F., Attali, B., Lazdunski, M., and Barhanin, J. (1992). Developmental expression of voltage-sensitive $\mathrm{K}+$ channels in mouse skeletal muscle and $\mathrm{C} 2 \mathrm{C} 12$ cells. FEBS Lett. 310, 162-166. doi: 10.1016/00145793(92)81320-L

Liu, J., Feng, S., Zhang, L., Wu, Z., Chen, Q., Cheng, W., et al. (2010). [Expression and properties of potassium channels in human mammary epithelial cell line MCF10A and its possible role in proliferation]. Sheng Li Xue Bao 62, 203-209.

Liu, S. I., Chi, C. W., Lui, W. Y., Mok, K. T., Wu, C. W., and Wu, S. N. (1998). Correlation of hepatocyte growth factor-induced proliferation and calcium-activated potassium current in human gastric cancer cells. Biochim. Biophys. Acta. 1368, 256-266. doi: 10.1016/S00052736(97)00183-1

MacFarlane, S. N., and Sontheimer, H. (2000). Modulation of Kv1.5 currents by Src tyrosine phosphorylation: potential role in the differentiation of astrocytes. J. Neurosci. 20, 5245-5253.

Mauro, T., Dixon, D. B., Komuves, L., Hanley, K., and Pappone, P. A. (1997). Keratinocyte K+ channels mediate $\mathrm{Ca} 2+$-induced differentiation. J. Invest. Dermatol. 108, 864-870. doi: 10.1111/1523-1747. ep12292585

McCormack, T., McCormack, K., Nadal, M. S., Vieira, E., Ozaita, A. and Rudy, B. (1999). The effects of Shaker beta-subunits on the human lymphocyte $\mathrm{K}+$ channel Kv1.3. J. Biol. Chem. 274, 20123-20126. doi: 10.1074/jbc.274.29.20123

Michelakis, E. D., Reeve, H. L., Huang, J. M., Tolarova, S., Nelson, D. P., Weir, E. K., et al. (1997). Potassium channel diversity in vascular smooth muscle cells. Can. J. Physiol. Pharmacol. 75, 889-897. doi: 10.1139/y97-111

Mullen, K. M., Rozycka, M., Rus, H., Hu, L., Cudrici, C., Zafranskaia, E., et al. (2006). Potassium channels Kv1.3 and Kv1.5 are expressed on blood-derived dendritic cells in the central nervous system. Ann. Neurol. 60, 118-127. doi: 10.1002/ ana.20884

Nakahira, K., Shi, G., Rhodes, K. J., and Trimmer, J. S. (1996). Selective interaction of voltagegated $\mathrm{K}+$ channel beta-subunits with alpha-subunits. J. Biol. Chem. 271, 7084-7089. doi: 10.1074/jbc. 271.12.7084

Nilius, B., and Wohlrab, W. (1992). Potassium channels and regulation of proliferation of human melanoma cells. J. Physiol. 445, 537-548.

O'Grady, S. M., and Lee, S. Y. (2005). Molecular diversity and function of voltage-gated $(\mathrm{Kv})$ potassium channels in epithelial cells. Int. J. Biochem. Cell. Biol. 37, 1578-1594. doi: 10.1016/j.biocel.2005.04.002

Pancrazio, J. J., Tabbara, I. A., and Kim, Y. I. (1993). Voltage-activated K+ conductance and cell proliferation in small-cell lung cancer. Anticancer Res. 13, 1231-1234.

Panyi, G. (2005). Biophysical and pharmacological aspects of $\mathrm{K}+$ channels in T lymphocytes. Eur. Biophys. J. 34, 515-529.

Panyi, G., Varga, Z., and Gaspar, R. (2004). Ion channels and lymphocyte activation. Immunol. Lett. 92, 55-66. doi: 10.1016/j.imlet. 2003.11.020

Pardo, L. A. (2004). Voltage-gated potassium channels in cell proliferation. Physiology (Bethesda) 19, 285-292. doi: 10.1152/physiol. 00011.2004

Pardo, L. A., Contreras-Jurado, C., Zientkowska, M., Alves, F., and Stuhmer, W. (2005). Role of voltagegated potassium channels in cancer. J. Membr. Biol. 205, 115-124. doi: 10.1007/s00232-005-0776-1

Partiseti, M., Korn, H., and Choquet, D. (1993). Pattern of potassium channel expression in proliferating B lymphocytes depends upon the mode of activation. J. Immunol. 151, 2462-2470.

Preußat, K., Beetz, C., Schrey, M., Kraft, R., Wolfl, S., Kalff, R., et al. (2003). Expression of voltage-gated potassium channels Kv1.3 and Kv1.5 in human gliomas. Neurosci. Lett. 346, 33-36. doi: 10.1016/S03043940(03)00562-7

Rane, S. G. (2000). The growth regulatory fibroblast IK channel is the prominent electrophysiological feature of rat prostatic cancer cells. Biochem. Biophys. Res. Commun. 269, 457-463. doi: 10.1006/bbrc.20 00.2309

Rangaraju, S., Chi, V., Pennington, M. W., and Chandy, K. G. (2009). Kv1.3 potassium channels as a therapeutic target in multiple sclerosis. Expert Opin. Ther. Targets 13, 909-924. doi: 10.1517/14728220903018957

Roberds, S. L., and Tamkun, M. M. (1991). Developmental expression of cloned cardiac potassium channels. FEBS Lett. 284, 152-154. doi: 10.1016/0014-5793(91)80673-Q

Roderick, C., Reinach, P. S., Wang, L., and Lu, L. (2003). Modulation of rabbit corneal epithelial cell proliferation by growth factorregulated $\mathrm{K}(+)$ channel activity. J. Membr. Biol. 196, 41-50. doi: 10.1007/s00232-003-0623-1

Roura-Ferrer, M., Sole, L., MartinezMarmol, R., Villalonga, N., and Felipe, A. (2008). Skeletal muscle Kv7 (KCNQ) channels in myoblast differentiation and proliferation. Biochem. Biophys. Res. Commun. 369, 1094-1097. doi: 10.1016/j. bbrc.2008.02.152

Rouzaire-Dubois, B., and Dubois, J. M. (1998). K+ channel block-induced mammalian neuroblastoma cell swelling: a possible mechanism to influence proliferation. J. Physiol. 510(Pt 1), 93-102. doi: 10.1111/j.1469-7793.1998.093bz.x

Rouzaire-Dubois, B., Malo, M., Milandri, J. B., and Dubois, J. M. 
(2004). Cell size-proliferation relationship in rat glioma cells. Glia 45, 249-257. doi: 10.1002/glia.10320

Rybalchenko, V., Prevarskaya, N., Van Coppenolle, F., Legrand, G., Lemonnier, L., Le Bourhis, X., et al. (2001). Verapamil inhibits proliferation of LNCaP human prostate cancer cells influencing $\mathrm{K}+$ channel gating. Mol. Pharmacol. 59, 1376-1387.

Sewing, S., Roeper, J., and Pongs, O. (1996). Kv beta 1 subunit binding specific for shaker-related potassium channel alpha subunits. Neuron 16, 455-463. doi: 10.1016/ S0896-6273(00)80063-X

Shah, K., Tom Blake, J., Huang, C., Fischer, P., and Koo, G. C. (2003). Immunosuppressive effects of a Kv1.3 inhibitor. Cell. Immunol. 221, 100-106. doi: 10.1016/S0008-8749 (03)00063-7

Skryma, R. N., Prevarskaya, N. B., Dufy-Barbe, L., Odessa, M. F., Audin, J., and Dufy, B. (1997). Potassium conductance in the androgen-sensitive prostate cancer cell line, LNCaP: involvement in cell proliferation. Prostate 33, 112-122. doi: 10.1002/(SICI)10970045(19971001)33:2<112::AID-PR OS5 > 3.0.CO;2-M

Sole, L., Roura-Ferrer, M., PerezVerdaguer, M., Oliveras, A., Calvo, M., Fernandez-Fernandez, J. M., et al. (2009). KCNE4 suppresses Kv1.3 currents by modulating trafficking, surface expression and channel gating. J. Cell Sci. 122, 3738-3748. doi: 10.1242/jcs.056689

Soliven, B., Ma, L., Bae, H., Attali, B., Sobko, A., and Iwase, T. (2003). PDGF upregulates delayed rectifier via $\mathrm{Src}$ family kinases and sphingosine kinase in oligodendroglial progenitors. Am. J. Physiol. Cell. Physiol. 284, C85-C93. doi: 10.1152/ajpcell.00145.2002

Sontheimer, H. (1994). Voltagedependent ion channels in glial cells. Glia 11, 156-172. doi: 10.1002/glia.440110210

Storey, N. M., Gomez-Angelats, M., Bortner, C. D., Armstrong, D. L., and Cidlowski, J. A. (2003). Stimulation of Kv1.3 potassium channels by death receptors during apoptosis in Jurkat T lymphocytes. J. Biol. Chem. 278, 33319-33326. doi: $10.1074 /$ jbc.M300443200

Strobl, J. S., Wonderlin, W. F., and Flynn, D. C. (1995). Mitogenic signal transduction in human breast cancer cells. Gen. Pharmacol. 26, 1643-1649. doi: 10.1016/0306-3623 (95)00062-3

Stuhmer, W., Alves, F., Hartung, F., Zientkowska, M., and Pardo, L.
A. (2006). Potassium channels as tumour markers. FEBS Lett. 580, 2850-2852. doi: 10.1016/j.febslet. 2006.03.062

Stuhmer, W., Ruppersberg, J. P., Schroter, K. H., Sakmann, B., Stocker, M., Giese, K. P., et al. (1989). Molecular basis of functional diversity of voltage-gated potassium channels in mammalian brain. EMBO J. 8, 3235-3244.

Swanson, R., Marshall, J., Smith, J. S., Williams, J. B., Boyle, M. B., Folander, K., et al. (1990). Cloning and expression of cDNA and genomic clones encoding three delayed rectifier potassium channels in rat brain. Neuron 4, 929-939. doi: $\quad 10.1016 / 0896-6273(90)$ 90146-7

Szabo, I., Adams, C., and Gulbins, E. (2004). Ion channels and membrane rafts in apoptosis. Pflugers Arch. 448, 304-312. doi: 10.1007/s00424-0041259-4

Szabo, I., Bock, J., Grassme, H., Soddemann, M., Wilker, B., Lang, F., et al. (2008). Mitochondrial potassium channel Kv1.3 mediates Bax-induced apoptosis in lymphocytes. Proc. Natl. Acad. Sci. U.S.A. 105, 14861-14866. doi: 10.1073/ pnas.0804236105

Szabo, I., Zoratti, M., and Gulbins, E. (2010). Contribution of voltagegated potassium channels to the regulation of apoptosis. FEBS Lett. 584, 2049-2056. doi: 10.1016/j.febslet. 2010.01.038

Tamkun, M. M., Knoth, K. M., Walbridge, J. A., Kroemer, H., Roden, D. M., and Glover, D. M. (1991). Molecular cloning and characterization of two voltage-gated $\mathrm{K}+$ channel cDNAs from human ventricle. Faseb J. 5, 331-337.

Tsevi, I., Vicente, R., Grande, M., Lopez-Iglesias, C., Figueras, A., Capella, G., et al. (2005). KCNQ1/KCNE1 channels during germ-cell differentiation in the rat: expression associated with testis pathologies. J. Cell. Physiol. 202, 400-410. doi: 10.1002/jcp.20132

Utermark, T., Alekov, A., Lerche, H., Abramowski, V., Giovannini, M., and Hanemann, C. O. (2003). Quinidine impairs proliferation of neurofibromatosis type 2-deficient human malignant mesothelioma cells. Cancer 97, 1955-1962. doi: 10. 1002/cncr.11275

Vallejo-Gracia, A., Bielanska, J., Hernandez-Losa, J., Castellvi, J., Ruiz-Marcellan, M. C., Ramon, Y. C. S., et al. (2013). Emerging role for the voltage-dependent $\mathrm{K}+$ channel Kv1.5 in B-lymphocyte physiology: expression associated with human lymphoma malignancy. J. Leukoc. Biol. 94, 779-789. doi: 10.1189/jlb. 0213094

Vaupel, P., Mayer, A., and Hockel, M. (2004). Tumor hypoxia and malignant progression. Methods Enzymol. 381, 335-354. doi: 10.1016/S00766879(04)81023-1

Vaur, S., Bresson-Bepoldin, L., Dufy, B., Tuffet, S., and Dufy-Barbe, L. (1998). Potassium channel inhibition reduces cell proliferation in the GH3 pituitary cell line. J. Cell. Physiol. 177, 402-410. doi: 10.1002/ (SICI) 1097-4652(199812) 177:3<40 2::AID-JCP4>3.0.CO;2-Z

Vautier, F., Belachew, S., Chittajallu, R., and Gallo, V. (2004). Shaker-type potassium channel subunits differentially control oligodendrocyte progenitor proliferation. Glia 48, 337-345. doi: 10.1002/glia.20088

Veh, R. W., Lichtinghagen, R., Sewing, S., Wunder, F., Grumbach, I. M., and Pongs, O. (1995). Immunohistochemical localization of five members of the Kv1 channel subunits: contrasting subcellular locations and neuron-specific co-localizations in rat brain. Eur. J. Neurosci. 7, 2189-2205. doi: 10. 1111/j.1460-9568.1995.tb00641.x

Vennekamp, J., Wulff, H., Beeton, C., Calabresi, P. A., Grissmer, S. Hansel, W., et al. (2004). Kv1.3blocking 5-phenylalkoxypsoralens: a new class of immunomodulators. Mol. Pharmacol. 65, 1364-1374. doi: 10.1124/mol.65.6.1364

Verkhratsky, A., and Steinhauser, C. (2000). Ion channels in glial cells. Brain Res. Brain Res. Rev. 32, 380-412. doi: 10.1016/S0165-0173 (99)00093-4

Vicente, R., Escalada, A., Coma, M., Fuster, G., Sanchez-Tillo, E., Lopez-Iglesias, C., et al. (2003). Differential voltage-dependent $\mathrm{K}+$ channel responses during proliferation and activation in macrophages. J. Biol. Chem. 278, 46307-46320. doi: 10.1074/jbc M304388200

Vicente, R., Escalada, A., Soler, C., Grande, M., Celada, A., Tamkun, M. M., et al. (2005). Pattern of Kv beta subunit expression in macrophages depends upon proliferation and the mode of activation. J. Immunol. 174 4736-4744.

Vicente, R., Escalada, A., Villalonga, N., Texido, L., Roura-Ferrer, M., Martin-Satue, M., et al. (2006). Association of Kv1.5 and $\mathrm{Kv1.3}$ contributes to the major voltage-dependent $\mathrm{K}+$ channel in macrophages. J. Biol. Chem. 281, 37675-37685. doi: 10.1074/jbc. M605617200
Vicente, R., Villalonga, N., Calvo, M., Escalada, A., Solsona, C., Soler, C., et al. (2008). Kv1.5 association modifies Kv1.3 traffic and membrane localization. J. Biol. Chem. 283, 8756-8764. doi: 10.1074/jbc.M708223200

Vigdor-Alboim, S., Rothman, C., Braiman, L., Bak, A., Langzam, L., Yosef, O., et al. (1999). Discoordinate regulation of different $\mathrm{K}$ channels in cultured rat skeletal muscle by nerve growth factor. J. Neurosci. Res. 56, 275-283. doi: $\quad 10.1002 /($ SICI) 1097-4547(19 990501)56:3<275::AID-JNR7>3.3. CO;2-I

Villalonga, N., David, M., Bielanska, J., Gonzalez, T., Parra, D., Soler, C., et al. (2010a). Immunomodulatory effects of diclofenac in leukocytes through the targeting of $\mathrm{Kv} 1.3$ voltage-dependent potassium channels. Biochem. Pharmacol. 80 858-866. doi: 10.1016/j.bcp.2010. 05.012

Villalonga, N., David, M., Bielanska, J., Vicente, R., Comes, N., Valenzuela, C., et al. (2010b). Immunomodulation of voltagedependent $\mathrm{K}^{+}$channels in macrophages: molecular and biophysical consequences. J. Gen. Physiol. 135, 135-147. doi: 10.1085/ jgp.200910334

Villalonga, N., Escalada, A., Vicente, R., Sanchez-Tillo, E., Celada, A., Solsona, C., et al. (2007a). Kv1.3/Kv1.5 heteromeric channels compromise pharmacological responses in macrophages. Biochem. Biophys. Res. Commun. 352, 913-918. doi: 10.1016/j.bbrc.2006. 11.120

Villalonga, N., Ferreres, J. C., Argiles, J. M., Condom, E., and Felipe, A. (2007b). Potassium channels are a new target field in anticancer drug design. Recent Pat. Anticancer Drug Discov. 2, 212-223. doi: 10.2174/ 157489207782497181

Villalonga, N., Martinez-Marmol, R., Roura-Ferrer, M., David, M., Valenzuela, C., Soler, C., et al. (2008). Cell cycle-dependent expression of Kv1.5 is involved in myoblast proliferation. Biochim. Biophys. Acta. 1783, 728-736. doi: 10.1016/j.bbamcr.2008.01.001

Wang, L., Shao, G., Zhang, W., Guo, X., Wang, C., An, J., et al. (2002). Influence of 4-aminopyridine on voltage-activated $\mathrm{K}(+)$ current and cell proliferation in small cell lung cancer. Zhonghua Zhong Liu Za Zhi 24, 230-233.

Wang, L., Xu, B., White, R. E., and Lu, L. (1997). Growth factor-mediated $\mathrm{K}+$ channel activity associated with 
human myeloblastic ML-1 cell proliferation. Am. J. Physiol. 273, C1657-C1665.

Wang, Z. (2004). Roles of K+ channels in regulating tumour cell proliferation and apoptosis. Pflugers Arch. 448, 274-286. doi: 10.1007/s00424004-1258-5

Wickenden, A. (2002). K(+) channels as therapeutic drug targets. Pharmacol. Ther. 94, 157-182. doi: 10.1016/S0163-7258(02)00201-2

Wohlrab, D., Lebek, S., Kruger, T., and Reichel, H. (2002). Influence of ion channels on the proliferation of human chondrocytes. Biorheology 39, 55-61.

Wohlrab, D., and Markwardt, F. (1999). Influence of ion channel blockers on proliferation and free intracellular $\mathrm{Ca} 2+$ concentration of human keratinocytes. Skin Pharmacol. Appl. Skin Physiol. 12, 257-265. doi: 10.1159/000066250

Wonderlin, W. F., and Strobl, J. S. (1996). Potassium channels, proliferation and G1 progression. J. Membr. Biol. 154, 91-107. doi: 10.1007/s002329900135

Wong, J. Y., Huggins, G. S., Debidda, M., Munshi, N. C., and De Vivo, I. (2008). Dichloroacetate induces apoptosis in endometrial cancer cells. Gynecol. Oncol. 109, 394-402. doi: 10.1016/j.ygyno.2008.01.038

Wu, H., Wu, K., Han, Y., Shi, Y., Yao, L., Wang, J., et al. (2002). Delayed rectifier $\mathrm{K}(+)$ channel regulated by cyclooxygenase-2 in human gastric cancer cell. Zhonghua Zhong Liu Za Zhi 24, 440-443.

Wulff, H., Beeton, C., and Chandy, K. G. (2003). Potassium channels as therapeutic targets for autoimmune disorders. Curr. Opin. Drug Discov. Devel. 6, 640-647.

Wulff, H., Knaus, H. G., Pennington, M., and Chandy, K. G. (2004). $\mathrm{K}+$ channel expression during $B$ cell differentiation: implications for immunomodulation and autoimmunity. J. Immunol. 173, 776-786.

Wulff, S., Pries, R., Borngen, K., Trenkle, T., and Wollenberg, B. (2009). Decreased levels of circulating regulatory NK cells in patients with head and neck cancer throughout all tumor stages. Anticancer Res. 29, 3053-3057.

Xu, D., Wang, L., Dai, W., and Lu, L. (1999). A requirement for $\mathrm{K}+$-channel activity in growth factor-mediated extracellular signal-regulated kinase activation in human myeloblastic leukemia ML-1 cells. Blood 94, 139-145.

Xu, J., Koni, P. A., Wang, P., Li, G., Kaczmarek, L., Wu, Y., et al. (2003). The voltage-gated potassium channel Kv1.3 regulates energy homeostasis and body weight. Hum. Mol. Genet. 12, 551-559. doi: 10.1093/ hmg/ddg049

Xu, J., Wang, P., Li, Y., Li, G., Kaczmarek, L. K., Wu, Y., et al.
(2004). The voltage-gated potassium channel Kv1.3 regulates peripheral insulin sensitivity. Proc. Natl. Acad. Sci. U.S.A. 101, 3112-3117. doi: 10.1073/pnas.0308 450100

Yao, X., and Kwan, H. Y. (1999). Activity of voltage-gated $\mathrm{K}+$ channels is associated with cell proliferation and $\mathrm{Ca} 2+$ influx in carcinoma cells of colon cancer. Life Sci. 65, 55-62. doi: 10.1016/S0024-3205(99)00218-0

Yuan, X. J., Wang, J., Juhaszova, M., Golovina, V. A., and Rubin, L. J. (1998). Molecular basis and function of voltage-gated $\mathrm{K}+$ channels in pulmonary arterial smooth muscle cells. Am. J. Physiol. 274, L621-L635.

Zhou, Q., Kwan, H. Y., Chan, H. C., Jiang, J. L., Tam, S. C., and Yao, X. (2003). Blockage of voltagegated $\mathrm{K}+$ channels inhibits adhesion and proliferation of hepatocarcinoma cells. Int. J. Mol. Med. 11, 261-266.

Zsiros, E., Kis-Toth, K., Hajdu, P., Gaspar, R., Bielanska, J., Felipe, A., et al. (2009). Developmental switch of the expression of ion channels in human dendritic cells J. Immunol. 183, 4483-4492. doi: 10.4049/jimmunol.0803003

Conflict of Interest Statement: The authors declare that the research was conducted in the absence of any commercial or financial relationships that could be construed as a potential conflict of interest.

Received: 23 May 2013; accepted: 18 September 2013; published online: 10 October 2013.

Citation: Comes N, Bielanska J, Vallejo-Gracia A, Serrano-Albarrás A, Marruecos L, Gómez D, Soler C, Condom E, Ramón y Cajal S, Hernández-Losa J, Ferreres JC and Felipe A (2013) The voltage-dependent $\mathrm{K}^{+}$channels Kv1.3 and Kv1.5 in human cancer. Front. Physiol. 4:283. doi: 10.3389/fphys. 2013.00283

This article was submitted to Membrane Physiology and Membrane Biophysics, a section of the journal Frontiers in Physiology.

Copyright (c) 2013 Comes, Bielanska, Vallejo-Gracia, Serrano-Albarrás, Marruecos, Gómez, Soler, Condom, Ramón y Cajal, Hernández-Losa, Ferreres and Felipe. This is an openaccess article distributed under the terms of the Creative Commons Attribution License (CC BY). The use, distribution or reproduction in other forums is permitted, provided the original author(s) or licensor are credited and that the original publication in this journal is cited, in accordance with accepted academic practice. No use, distribution or reproduction is permitted which does not comply with these terms. 